Bangladesh J. Plant Taxon. 20(1): 39-49, 2013 (June)

(C) 2013 Bangladesh Association of Plant Taxonomists

\title{
MEDICO-BOTANICAL STUDIES OF SANDWIP ISLAND IN CHITTAGONG, BANGLADESH
}

\author{
NoOR Hassan SAJIB AND S.B. UdDin ${ }^{1}$ \\ Department of Botany, University of Chittagong, Chittagong 4331, Bangladesh.
}

Keywords: Ethnobotany; Medicinal plants; Sandwip; Bangladesh.

\begin{abstract}
A study of the plant diversity of Sandwip Island has been conducted during July 2008 to April 2011 in order to document plant species used as traditional herbal medicine. A total of 111 species under 93 genera of 53 families have been documented which are used for the treatment of 48 diseases/illness. The local people of the island mostly depended on herbal medicine for their primary health care. Twenty one recorded medicinal plant species are used for the treatment of various types of pain, 14 each for dysentery and rheumatism, 8 each for cough and haemorrhages, 7 for skin diseases, 6 for worms, 5 for boils, 4 each for jaundice and fracture, 3 each for chicken pox, fever and diabetes and 54 for other diseases.
\end{abstract}

\section{Introduction}

Sandwip Island is an upazila in Chittagong district of Bangladesh with an area of $762.42 \mathrm{sq}$ $\mathrm{km}$ (Banglapedia, 2006). Most of the people directly or indirectly depend on plant resources of the area for their livelihood. In some areas of the island people are mostly dependent on the surrounding plants for their food, medicine, tools and crafts, fishing and agricultural tools. Bangladesh though is a small country has a valuable heritage of herbal remedies. Due to very low side effect, the use of medicinal plants is getting importance day by day.

Over the past two decades several ethnomedicinal and ethnobotanical studies in Bangladesh have been carried out (Mia and Rahman, 1990, Uddin et al., 2006; Yusuf et al., 2006, 2007; Partha and Hossain, 2007; Rahman et al., 2007; Roy et al., 2008; Alom et al., 2011; Faruque and Uddin, 2011; Chowdhury et al., 2011; Mohiuddin et al., 2012; Uddin et al., 2012). However, there is very limited information (Mia and Rahman, 1990) on the ethno-medicinal plants used by the Sandwip island communities. This study aims to document ethno-medicinal plants used for the treatment of different diseases/illness and to prepare conservation strategy for the medicinal plants of the island.

\section{Materials and Methods}

The ethnomedicinal data was documented following the direct observation, field interview and group interview from July 2008 to April 2011. A total of ten field trips were made for documentation. During the field interview, the information was noted in the documentation data sheet. All the information regarding plant species, biological forms, habitat, local names and uses was documented. Ethnomedicinal information was obtained through informal interviews following semi-structured and open-ended techniques (Alexiades, 1996) from knowledgeable persons particularly Kabiraj (local herbalist) and elderly people. All voucher specimens were collected during documentation and deposited in the Chittagong University Herbarium (HCU). The specimens were identified consulting with the experts, by comparing herbarium specimens and available literature (Hooker, 1872-1897; Prain, 1903; Heinig, 1925; Sinclair, 1956, Siddiqui et al., 2007; Ahmed et al., 2008, 2009; Rashid and Rahman, 2011, 2012).






\section{Results and Discussion}

A total of 111 medicinal plant species belonging to 93 genera under 53 families are used for the treatment of 48 diseases/illness. The scientific names, family names, local names, parts used, mode of use and uses are enumerated in Table 1 . Asteraceae is used most frequently as per the number of species. The most frequently used species for the treatment of different diseases are Acampe papilosa, Achyranthes aspera, Amoora rohituka, Azadirachta indica, Calotropis gigantea, Cassia alata, Chromolaena odorata, Clitoria ternetea, Coccinea grandis, Commelina benghalensis, Cynodon dactylon, Datura metel, Eclipta alba, Justicia adhatoda, Lawsonia inermis, Lygodium japonicum, Mikania cordata, Ocimum sanctum, Oroxylum indicum, Psidium guajava, Ricinus communis, Scoparia dulcis, Spilanthes calva, Swietenia mahagoni, Terminalia arjuna and Vitex negundo.

Regarding life form, herbs were $41.44 \%$, shrubs $16.22 \%$, trees $29.73 \%$ and climbers $12.61 \%$. The most utilized plant parts for the preparation of herbal medicine is leaf, constituting $40 \%$ followed by fruit, stem, bark, and roots amounting $14.4 \%, 11.2 \%, 7.2 \%, 6.4 \%$, whole plant $4 \%$ and others (thorn, bulb, rhizome, flower, seed, tuber, petiole, bud and node) 16.8\% respectively. Among the recorded medicinal plants to treat several diseases/illness 21 species are used to treat various types of pain, 14 each for dysentery and rheumatism, 8 each for cough and haemorrhages, 7 for skin diseases, 6 for worms, 5 for boils, 4 each for jaundice and fracture, 3 each for chicken pox, fever and diabetes and 54 for others.

The present study reveals that both external (27.34\%) and internal $(72.66 \%)$ methods of application of herbal medicine are prescribed. The dose and duration of application of these medicinal preparations vary from informant to informant. Most of the extracts are taken in the morning. It may be required 1-7 days to cure/control the diseases and in some cases it may take up to 3 months. Medicines administered orally include those claimed to be used mainly for treating fever, cough, diabetics, jaundice, worms, diarrhoea, dysentery and gastritis. On the other hand, medicines recommended to be applied externally include treating boils, skin disease, eye disease, ear-ache, body swelling, headache, bruising, fracture and rheumatism.

Mia and Rahman (1990) reported 26 ethnomedicinal plants from Sandwip where they have cited only two plants as fish poison with no medicinal uses, while the present study recorded 111 species. From the study it is revealed that the community of Sandwip is rich in knowledge of medicinal plant use information. In the present study 17 species have been found same from the previous study, of which 8 species have the same uses with the present study with additional medicinal use information of 3 species. The remaining 9 species have been found to be used for different diseases, but in previous study no medicinal uses of these species were reported. The present study identifies some rare medicinal plants, viz., Abrus precatorius L., Acampe papilosa (Lindl.) Lindl., Cissus quadrangularis L., Oroxylum indicum (L.) Vent, Rauvolfia serpentina Benth., R. tetraphylla L. and Rhynchostylis retusa (L.) Bl. The biodiversity of the island is decreasing rapidly with the disappearing the land in the sea because of climate change. As a result, the island tradition of medicinal plant use information is at risk. On the other hand, the establishment of modern medicinal health centres is in progress in many villages of the Upazila that may gradually change the existing pattern of indigenous knowledge system of healthcare. In modern days, they are losing their previous glorious heritage of plant use knowledge in an alarming rate because of urbanization, rapid shrinkage and degradation of forests. On the other hand, present generation lost the interest to continue their parental profession as it does not provide them proper financial support for their livelihood. It is necessary conserve the threatened medicinal plants from extinction and to document plant use information before disappearing permanently. 


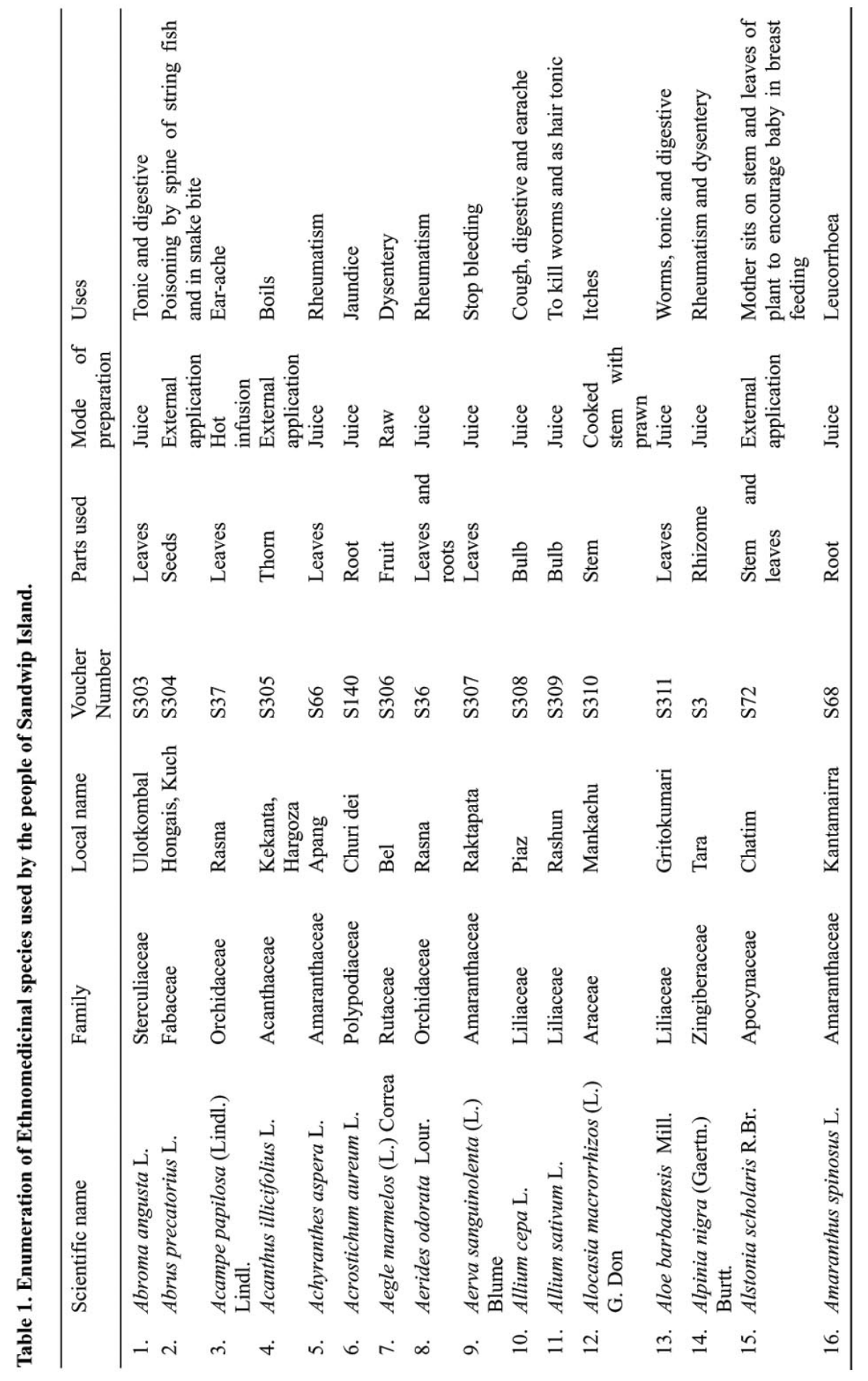




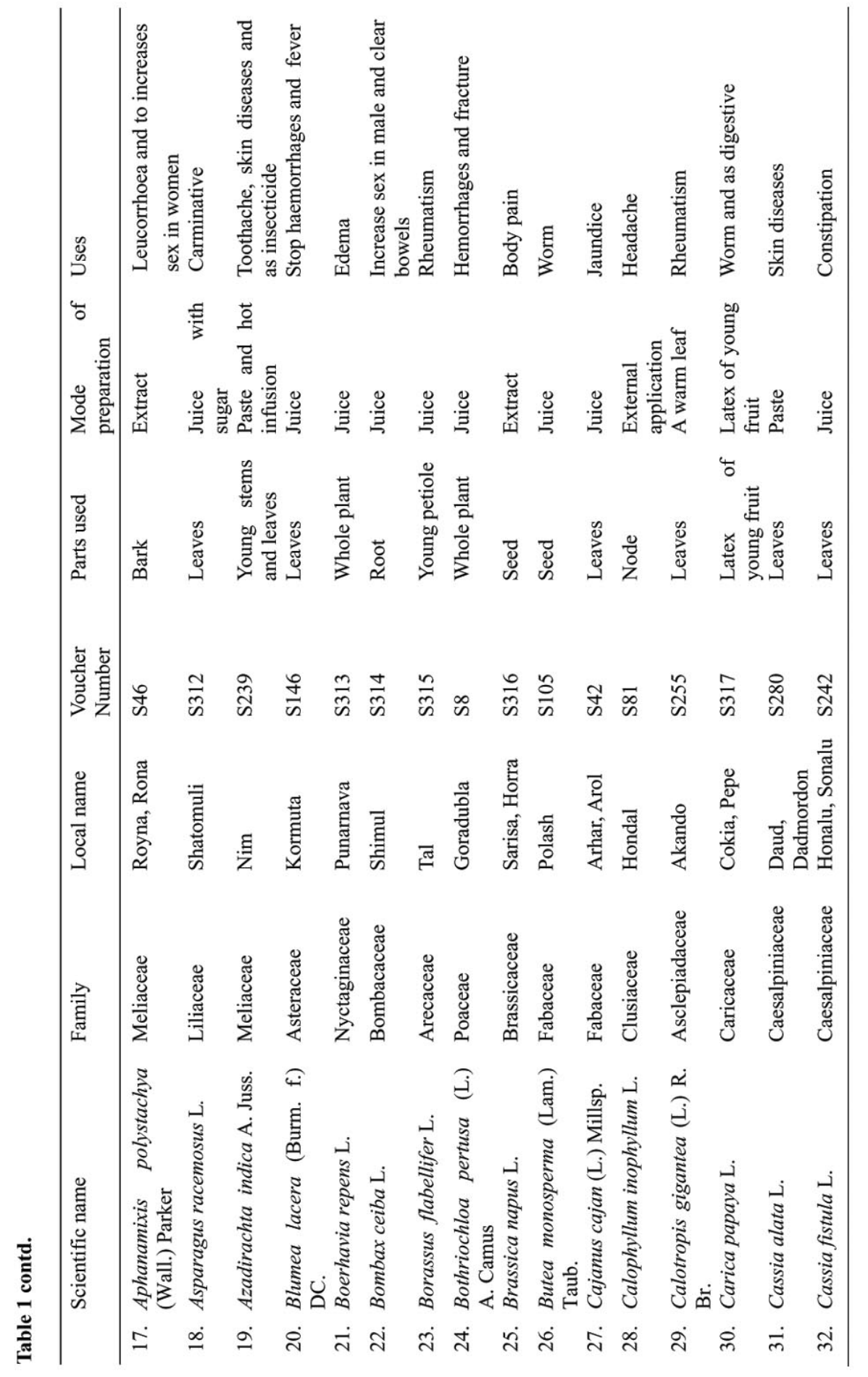




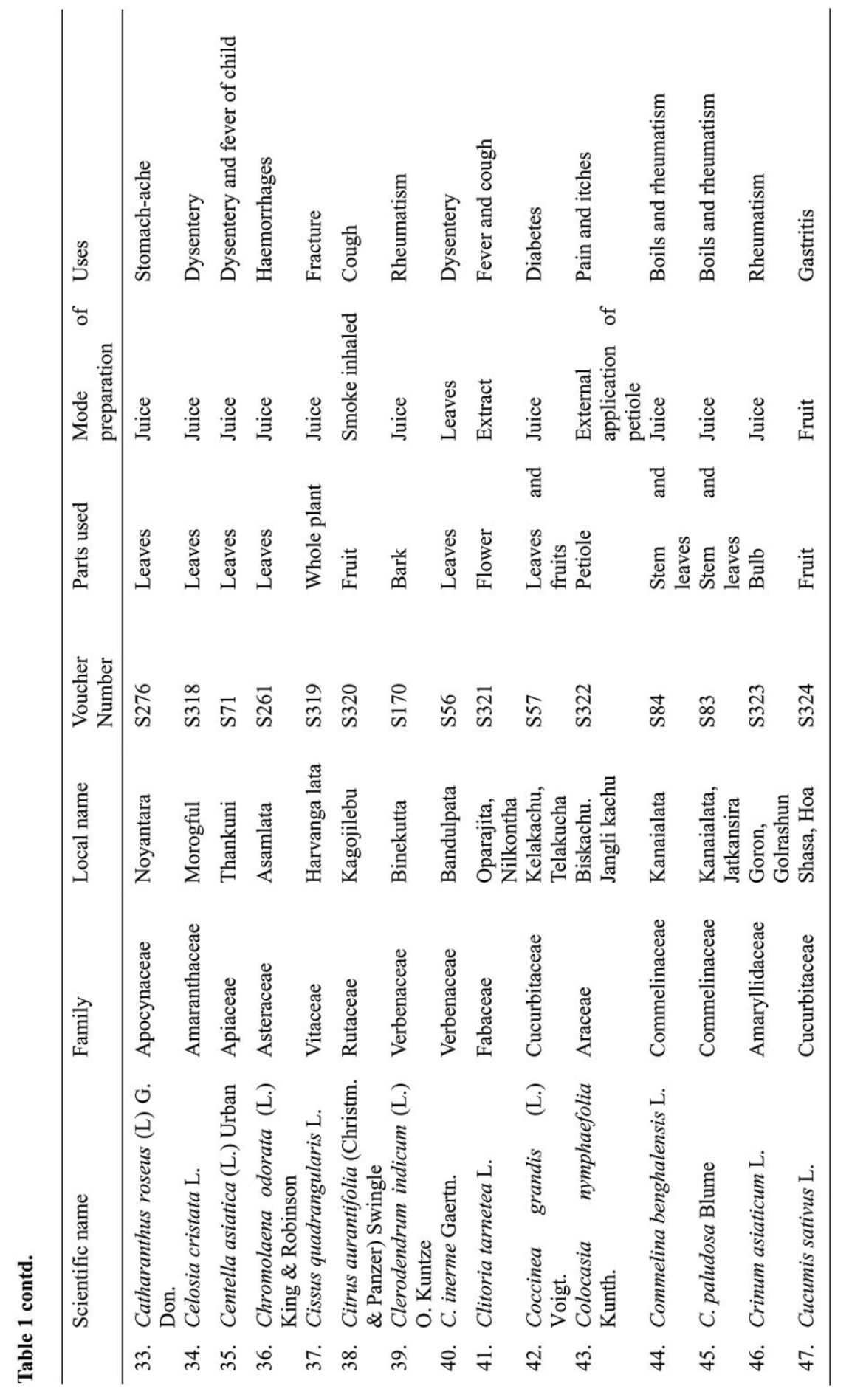




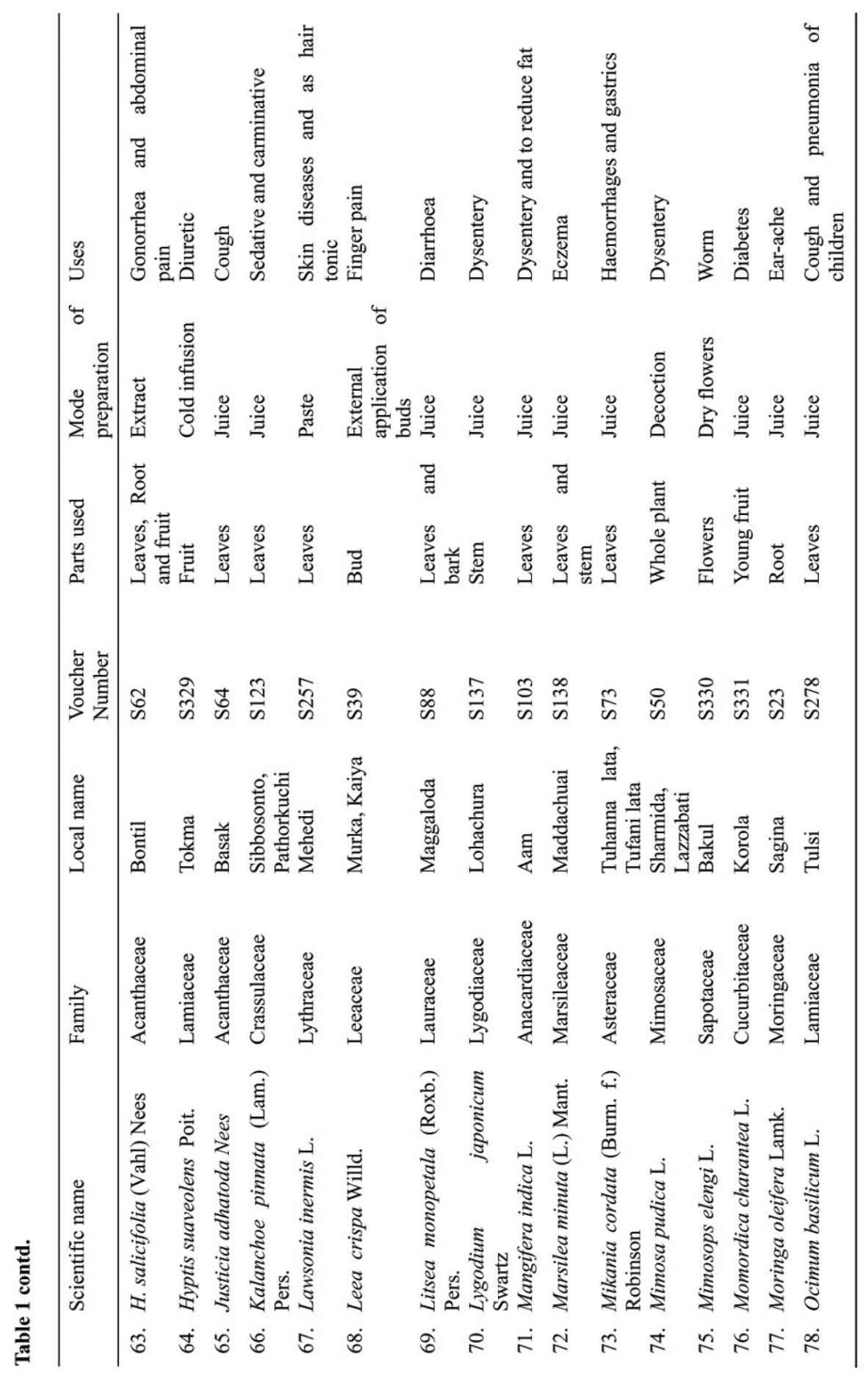














\section{Acknowledgements}

The authors express their deep sense of gratitude to the informants for their help during the field work. Authors are grateful to Prof. M.K. Pasha, Department of Botany, University of Chittagong for his valuable suggestions during preparation of the manuscript, and to identify some critical specimens.

\section{References}

Ahmed, Z.U., Begum, Z.N.T., Hassan, M.A., Khondker, M.M., Kabir, S.M.H., Ahmad, M., Ahmed, A.T.A., Rahman, A .K.A. and Haque, E.U. (Eds). 2008 -2009. Encyclopedia of Flora and Fauna of Bangladesh. 6-10. Angiosperms: Dicotyledons. Asiatic Society of Bangladesh, Dhaka.

Alexiades, M.N. 1996. Protocol for conducting ethnobotanical research in the tropics. In: Alexiades, M.N. and J.W. Sheldon (Eds) Selected Guidelines for Ethnobotanical Research: A Field Manual. The New York Botanical Garden, Bronx, New York, pp. 5-15.

Alom, M.N., Zohora, F. and Sultana, M. 2011. Ethnobotanical study of the Garo Tribe of Sherpur district, Bangladesh. J. Taxon. Biodiv. Res. 5: 39-42.

Banglapedia 2006. Sandwip upazila. Asiatic Society of Bangladesh, Dhaka. Website: <http://www. banglapedia.org/httpdocs/HT/S_0070.HTM>.

Chowdhury, T., Uddin, S.B., Quraishi, D.H. and Mouri, N.J. 2011. An ethnobotanical survey of plants of Sylhet in Bangladesh. Int. J. Current Res. 12(3): 31-35.

Faruque, O. and Uddin, S.B. 2011. Ethnodiversity of medicinal plants used by Tripura community of Chittagong district of Bangladesh. J. Taxon. Biodiv. Res. 5: 21-26.

Heinig, R.L. 1925. List of plants of Chittagong Collectorate and Hill tracts. Darjeeling, pp. 1-84.

Hooker, J.D. 1872-1897. The Flora of British India. Vols. 1-7. (Ind. Repr. 1973), Bishen Singh Mahendra Pal Singh, Dehra Dun, India.

Mia, M.M.K. and Rahman, M. 1990. Preliminary ethnomedicinal studies at Sandwip island of Bangladesh. In: Ghani, A. (Ed.), Traditional Medicine. Jahangirnagar University, Savar, Dhaka, pp. 104-108.

Mohiuddin, M., Alam, M.K., Basak, S.R. and Hossain, M.K. 2012. Ethno-medico botanical study among the four indigenous communities of Bandarban, Bangladesh. Bangladesh J. Plant Taxon. 19(1): 45-53.

Partha, P. and Hossain, A.B.M.E. 2007. Ethnobotanical investigation into the Mandi ethnic community in Bangladesh. Bangladesh J. Plant Taxon. 14(2): 129-145.

Prain, D. 1903. Bengal Plants. Vols. 1 \& 2. Indian Reprint Edition 1963, Calcutta.

Rahman, M.A., Uddin, S.B. and Wilcock, C.C. 2007. Medicinal plants used by Chakma tribe in hill tracts district of Bangladesh. Indian J. Traditional Knowledge 6(3): 508-517.

Rashid, M.E. and Rahman, M.A. 2011. Updated nomenclature and taxonomic status of the plants of Bangladesh included in Hook. f., The Flora of British India: Volume-I. Bangladesh J. Plant Taxon. 18(2): 177-197.

Rashid, M.E. and Rahman, M.A. 2012. Updated nomenclature and taxonomic status of the plants of Bangladesh included in Hook. f., The Flora of British India: Volume-II. Bangladesh J. Plant Taxon. 19(2): 173-190.

Roy, S., Uddin, M.Z., Hassan, M.A. and Rahman, M.M. 2008. Medico-botanical report on the Chakma community of Bangladesh. Bangladesh J. Plant Taxon. 15(1): 67-72.

Siddiqui, K.U., Islam, M.A., Ahmed, Z.U., Begum, Z.N.T., Hassan, M.A., Khondker, M., Rahman, M.M., Kabir, S.M.H., Ahmad, M., Ahmed, A.T.A., Rahman, A.K.A. and Haque, E.U. (Eds). 2007. Encyclopedia of Flora and Fauna of Bangladesh. Vol. 11. Angiosperms: Monocotyledons. Asiatic Society of Bangladesh, Dhaka.

Sinclair, J. 1956. The Flora of Cox’s Bazar. East Pakistan Bull. Bot. Soc. Beng. 9(2): 84-116.

Uddin, M.Z., Hassan, M.A. and Sultana, M. 2006. Ethnobotanical survey of medicinal plants in Phulbari Upazila of Dinajpur district, Bangladesh. Bangladesh J. Plant Taxon. 13(1): 63-68. 
Uddin, M.Z., Hassan, M.A., Rahman, M. and Arefin, K. 2012. Ethno-medico-botanical study in Lawachara National park, Bangladesh. Bangladesh J. Bot. 41(1): 97-104.

Yusuf, M., Wahab, M.A. and Chowdhury J.U. 2006. Ethno-medico-botanical knowledge from Kauhkali proper and Betbunia of Rangamati district. Bangladesh J. Plant Taxon. 13(1): 55-61.

Yusuf, M., Wahab, M.A., Yousuf, M., Chowdhury, J.U. and Begum, J. 2007. Some tribal medicinal plants of Chittagong Hill Tracts, Bangladesh. Bangladesh J. Plant Taxon. 14(2): 117-128.

(Manuscript received on 15 July 2011; revised on 25 January 2013) 